\title{
Records management: a basis for organizational learning and innovation
}

\author{
Gestão de documentos: bases para a aprendizagem \\ e inovação organizacional
}

Francisco José Aragão Pedroza CUNHA ${ }^{1}$

Núbia Moura RIBEIRO2

Hernane Borges de Barros PEREIRA ${ }^{3}$

\begin{abstract}
The understanding of (trans)formations related to organizational learning processes and knowledge recording can promote innovation. The objective of this study was to review the conceptual contributions of several studies regarding Organizational Learning and Records Management and to highlight the importance of knowledge records as an advanced management technique for the development and attainment of innovation. To accomplish this goal, an exploratory and multidisciplinary literature review was conducted. The results indicated that the identification and application of management models to represent knowledge is a challenge for organizations aiming to promote conditions for the creation and use of knowledge in order to transform it into organizational innovation. Organizations can create spaces and environments for local, regional, national, and global exchange with the strategic goal of generating and sharing knowledge, provided they know how to utilize Records Management mechanisms.
\end{abstract}

Keywords: Knowledge. Organizational learning and innovation. Records management.

\section{Resumo}

Entender as (trans)formações das organizações à luz dos processos de aprendizagem organizacional vinculados aos do registro do conhecimento érecomendável para a promoção de inovações. O objetivo deste manuscrito é revisar aportes conceituais multirreferenciais sobre a aprendizagem organizacional e a gestão de documentos e destacar a importância dos registros do conhecimento como uma das técnicas de gerenciamento avançado para o desenvolvimento e o alcance de inovações. Para isso, utilizou-se uma revisão de literatura de caráter exploratório e multidisciplinar. Conclui-se que a identificação e aplicação de modelos de gestão para representar o conhecimento é um desafio para organizações que visam promover condições de criação e uso do conhecimento, transformando-o em inovações organizacionais. As organizações podem confirmar ou criar espaços e ambientes de trocas local, regional, nacional ou global com a finalidade estratégica de gerar e compartilhar conhecimentos desde que saibam utilizar mecanismos de gestão de documentos.

Palavras-chave: Conhecimento. Aprendizagem e inovação organizacional. Gestão de documentos.

\footnotetext{
1 Professor Doutor, Universidade Federal da Bahia, Instituto de Ciência da Informação, Programa de Pós-Graduação em Ciência da Informação. Campus Universitário do Canela. Av. Reitor Miguel Calmon, s/n., Vale do Canela, 40110-100, Salvador, BA, Brasil. Correspondência para/Correspondence to: F.J.A.P. CUNHA. E-mail:<pedrozaici@gmail.com>.

2 Professora Doutora, Instituto Federal de Educação, Ciência e Tecnologia, Programa de Pós-Graduação Multidisciplinar e Multinstitucional em Difusão do Conhecimento. Salvador, BA, Brasil.

3 Professor Doutor, Serviço Nacional de Aprendizagem Industrial, Programa de Modelagem Computacional. Salvador, BA, Brasil. Received on 10/19/2012, resubmitted on 11/22/2012 and approved for publication on 11/28/2012.
} 


\section{Introduction}

Present-day society faces the challenge of accepting an extraordinarily broad diversity of cultural and ethnic groups and individuals. From this perspective, mechanistic or deterministic views are not the only ones that should be considered in the attempt to understand social phenomena (Morin, 2005a, 2005b; Bourdieu, 2009). Organizations are not excluded from such views and a strong information flow is continually impacting them and affecting their actions in space and time (Rousseau; Couture, 1998).

The way for organizations to differentiate themselves is related to their ability to access information and, above all, to learn, assimilate, and address innovation. This fact implies the adoption and assimilation of Records Management among individuals and organizations, as an initial Knowledge Management process to make Organizational Learning feasible and thereby promote innovation.

Therefore, it is advisable to understand recent (trans)formations and innovations with regard to the processes of Organizational Learning linked to knowledge records. These parameters can be contextualized as social, technical, and cognitive phenomena and are dependent on a form of Records Management that enables Knowledge Management to promote Organizational Learning.

However, the relationship between Organizational Learning and Records Management must first be defined. The objective of this study was to review conceptual contributions from several studies regarding Organizational Learning and Records Management as well as to highlight the importance of knowledge representation processes as a technique for advanced management to promote innovation.

Rousseau and Couture (1998, p.55, our translation) emphasized that "Organizations change attitude when challenged with information and move towards recognizing informational resources" ${ }^{4}$. Therefore, the Records Management intrinsic to Knowledge Management is justified, and performing this action in an effective manner will contribute directly to Organizational Learning and the innovative capacity of organizations/Records Management is essential for Knowledge Management as it becomes an effective way to contribute directly to Organizational Learning and the innovative capacity of organizations.

The methodological approach is multidisciplinary (involving Information Science, Archivology, Sociology, Administration, and Economics) because it involves a conceptual framework related to the phenomenon of Organizational Learning linked to knowledge records. Given the complexity of the subject, a multiple reference approach can be adopted, in which researchers provide a conceptual synthesis regarding the subject under investigation; more importantly, this approach is based on different viewpoints and reference systems that are not reducible to each other and that are made explicit by means of distinct approaches and terminologies (Fróes Burnham, 1998). Moreover, this approach can be used as part of a qualitative study for bibliographic and documental reviews, which fit the concept of basic research (Gil, 1994).

With the goal of achieving the stated objective, the present study provides a non-exhaustive review of Organizational Learning, Knowledge Management, and Records Management, and highlights the knowledge representation process as an open field for dialogue with Organizational Learning in the fields of Archivology and Information Science within the framework of these theoretical constructs.

\section{Double-loop learning and systems thinking}

Organizational Learning is understood as an ongoing process that arises from the sum of the individual learning of an organization's members but that exceeds this sum/from the sum of individual learning of group members but the sum of the group's achievements exceeds the sum of each individual's accomplishments. This process is characterized by interaction and collaboration between individuals and between working groups within social and technological systems, which work toward the development and change of organizational practices and consequently contribute to the promotion of organizational innovations (Vasconcelos; Mascarenhas, 2007; Takeuchi; Nonaka, 2008; Argyris, 2010; Senge, 2010).

\footnotetext{
4 "As organizações mudam de atitude face à informação e enveredam pelo movimento de reconhecimento dos recursos informacionais".
} 
According to the Organization for Economic Cooperation and Development (OECD) and the Financiadora de Estudose Projetos (FINEP, Funding Agency for Studies and Projects) -, organizational innovations consist of the adoption and incorporation of significantly altered organizational structures, advanced management techniques, and new or substantially altered strategic orientations (Financiadora de Estudos e Projetos, 2005).

Argyris (2010) emphasized that Organizational Learning is associated with the capacity of different parties that make up an organization to interact. This process relates to individuals when they seek to correct errors resulting from something that was carried out incorrectly. Therefore, Organizational Learning can be processed in two ways: by a single-loop or double-loop.

Single-loop learning occurs when an error is corrected, although without questioning the organizational action strategies (i.e., the variables or the values implicit in the action). Thus, learning is reflected only in the improvement of operational processes without altering the organization's guidelines. This type of learning causes the individuals to transform the action that resulted in the error, but they still operate based on the assumptions and values that underlie the action strategy. Consequently, new behaviors are not adopted (Argyris, 2010).

In double-loop learning, individuals question action strategies along with their intrinsic variables. According to Argyris (2010), this type of learning is characterized as a process in which individuals perceive and explore the possibilities of the environment by accessing new information. Later, those individuals compare the information that they have learned with the norms established for the operation of a given system. From that point, individuals adopt corrective actions in their organizational action strategies based on the questioning of normative variables of organizational action. These corrective actions result in changes in the procedures, guidelines, values, and assumptions of systems and organizational strategies (Argyris, 2010).

This learning model leverages the possibilities of Organizational Innovation, and Organizational Learning results from emergent and creative strategies that promote inventions. Then, after these inventions are incorporated into the mental images and representations of individuals, which require Records Management for organizational memory, they result in innovation once they are shared.

Within this context, the learning model suggested by Argyris (2010) can be associated with the model proposed by Senge (2010). Senge believes that individuals' interactions when sharing their knowledge play a role in transforming the organization into a learning organization. Members of these organizations consider this to be a system in which everyone's work affects the work of everyone else, i.e., a system that affects and is also affected by the environment in which it operates.

The ideas of Argyris (2010) and Senge (2010) are in agreement based on the premise that organizations are not isolated systems and that they are in a continuous process of course correction. Senge (2010) correlates the learning organization itself with innovation; for such to occur, it is expected that people adopt and develop behavioral skills, which are then translated into disciplines and/or technologies. The five disciplines proposed by Senge (2010) comprise a body of theory and practice that needs to be studied, learned, and mastered to be put into action (Table 1). Although these disciplines have been proposed for the field of administration, they can also be transferred to the work practice of information professionals, insofar as they are constantly requested to participate in the process of Organizational Learning in the organization where they act and from the perspective of contemporary archival practice (Rousseau; Couture, 1998).

For Senge (2010), Organizational Learning reaches its full expression when system thinking emerges. This type of thinking refers to the fact that individuals perceive two stages: 1) the vision of the organization as an interdependent whole, contrary to the linear chains of cause and effect, and 2) the perception of the processes of change, as opposed to fragmented and isolated facts in time and space. The particular characteristic of this type of thinking resides in the effect of feedback in human actions. These actions are reinforced or balanced among each other, evidencing the responsibility of organizational individuals in the actions that they institute and establishing the development of the cognitive skill of Organizational Learning. Such skill is associated with the recording, organization, treatment, and diffusion of 
Table 1. The five disciplines proposed by Senge.

\begin{tabular}{ll}
\hline Disciplines & Description \\
\hline Systems thinking & $\begin{array}{l}\text { The capacity to perceive that interrelated actions make up the whole (i.e., understand that everything is interlinked } \\
\text { and that organizations are complex systems). }\end{array}$ \\
Personal mastery & $\begin{array}{l}\text { The ability to clarify and deepen personal visions, focus energies, develop patience, and view reality objectively and } \\
\text { permanently (i.e., to have an open mind to reality and life with a creative and non-reactive attitude). }\end{array}$ \\
Mental models & $\begin{array}{l}\text { Deeply ingrained ideas, assumptions, and generalizations that influence how people understand the world and their } \\
\text { relationships (i.e., these are reflected in the principles and values of the organization). }\end{array}$ \\
Team learning & $\begin{array}{l}\text { The ability of team members to ignore their views and preconceptions to enable collective thinking; this is founded } \\
\text { in dialogue. }\end{array}$ \\
Shared vision & The (co)creation of a vision shared by all of the members of the organization.
\end{tabular}

Source: Cunha (2012), based on Senge (2010).

knowledge within the organization and is dependent upon the procedures and techniques that represent these factors.

\section{Knowledge management linked to organizational learning}

Organizational knowledge can be divided into tacit (or implicit) or codified (or explicit) knowledge (Polanyi, 1958). Explicit knowledge is that which is registered by means of signs (i.e., writing, drawing, images) or incorporated into tangible forms (i.e., machinery, tools), and this form of knowledge is formal and systematic. In contrast, tacit knowledge is personal and it is rooted in the action and commitment of the individual (i.e., occupation or profession), as well as in technical skills, mental models, beliefs, and perspectives (Santos, 2007; Takeuchi; Nonaka, 2008).

It is inferred that organizations depend on individuals' tacit knowledge. Therefore, tacit knowledge should be codified and registered. Records are documented and these "Govern the relationships between governments, organizations, and persons" (Rousseau; Couture, 1998, p.32, our translation) ${ }^{5}$. This fact provides a competitive advantage for organizations that can properly manage their knowledge.
The adoption of a Knowledge Management policy favors Organizational Learning, which can therefore be considered one of the guidelines for Knowledge Management itself. Whatever position adopted, some authors state that management is:

[...] is the process that directs individuals' competences and energies and uses material resources to reach a certain objective. [...] is also a set of techniques that allow one to make rational decisions and put them into practice so that all the individual's resources are used as best as possible bearing in mind the individual's efficacy (Guinchat; Menou, 1994, p.443, our translation) ${ }^{6}$.

Thus, managing knowledge:

[...] includes activities related to the acquisition, use and sharing of knowledge by the organization. This is an important part of the innovation process. Many studies about knowledge management practices have been done in recent years. They cover policies and strategies, leadership, knowledge acquisition, trainings and communications, as well as the reasons for the use of knowledge management practices and the motives that support the development of these practices (Financiadora de Estudos e Projetos, 2005, p.32, our translation, emphasis added)7.

It is recommended that Knowledge Management prioritize Records Management practices as one of the

\footnotetext{
5 "Regem as relações entre os governos, organizações e pessoas".

6 "[...] é o processo que dirige as competências e a energia dos indivíduos e atribui os recursos materiais, com a finalidade de atingir um determinado objetivo. [...] é também um conjunto de técnicas que permitem tomar decisões racionais e pôr estas em prática, para que todos os recursos do organismo sejam empregados da melhor forma possivel, tendo em vista a sua eficácia".

7 "[...] compreende atividades relacionadas à apreensão, uso e compartilhamento do conhecimento pela organização. Essa é uma importante parte do processo de inovação. Diversas pesquisas sobre práticas de gerenciamento do conhecimento foram realizadas nos últimos anos. Elas abordam políticas e estratégias, liderança, apreensão de conhecimento, treinamentos e comunicações, assim como as razões para o uso das práticas de gerenciamento do conhecimento e os motivos por trás do desenvolvimento dessas práticas."
} 
main types of management system. For Arantes (1998, p.88, our translation), these systems help to "Define the reason"8 of the organization; to plan, lead, organize, execute, monitor, and evaluate activities; "To establish understanding and relationships among people; to obtain information to operate and manage the enterprise, to mobilize people to perform the organizational task" ${ }^{\prime \prime}$. The management systems potentiate the transformation of information into knowledge as long as people create meaning for this information and incorporate it in their practices (Choo, 2003). "[...] the introduction of documental information, that is, of information that is recorded in a support through the aid of a preestablished code created a real revolution in the way of seeing and using information" (Rousseau; Couture, 1998, p.61, our translation) $)^{10}$.

According to the definition proposed by Santos (2007, p.176, our translation), Records Management corresponds "To the set of technical procedures and operations"11 regarding "The production, process, use, assessment, and filing of a document in a current and intermediate phase, aiming at its elimination or filing"12. Furthermore, Records Management is responsible for the monitoring and systematic assessment of "Document creation, reception, maintenance, use, and fate, including processes to capture and preserve the evidence of information about recorded activities and transactions" (Santos, 2007, p.190, our translation) ${ }^{13}$. Within this context, Knowledge Management can be conceived as "[...] the systematic process of identifying [recording], creating, renovating, and applying the knowledge that is strategic to the life of an organization" (Santos, 2007, p.191, our translation, emphasis added) ${ }^{\mathbf{1 4}}$.

In Knowledge Management, the focus is to some extent turned toward the results of the learning process (Loermans, 2002). However, these results are tied to the efficacy of the Records Management in organizations. The
Records Management makes it possible for organizations to create knowledge, disseminate it, and incorporate it into products, services, and systems, thereby promoting Organizational Learning to spur organizational innovations.

Considering the correlation between Knowledge Management and Records Management to be dependent upon Information Management. Information Management can be conceived of as a catalyzing process that is based on an organizational infrastructure (i.e., processes, people, and technological resources). The adoption of this management system (Figure 1) includes the stimulus for creating individual knowledge and learning as well as the systematic coordination of efforts at several levels, including organizational and individual, institutional and operational, and formal and informal norms with repercussions for satisfaction, wellbeing, and overall quality (Terra, 2001).

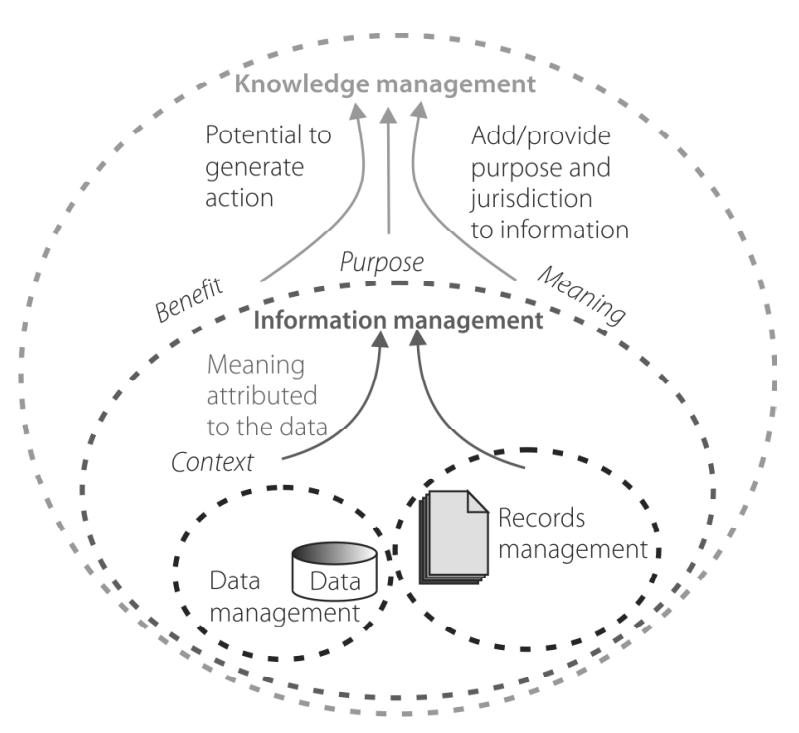

Figure 1. Relationship between data, Records Management, Information Management and Knowledge Management.

Source: Based on Santos (2007, p.197).

\footnotetext{
8 "Definir a razão".

9 "Aestabelecer o entendimento e as relaçöes entre as pessoas; a obter as informaçōes para operar egerenciar o empreendimento, a mobilizar as pessoas para realizar a tarefa organizacional."

10 "[...] a introdução da informação documental, istoé, da que se encontra registrada em um suporte com a ajuda de um código pré-estabelecido, criou uma verdadeira revolução na maneira de ver e de utilizar a informação".

11 "Ao conjunto de procedimentos e operações técnicas".

12 "Produção, tramitação, uso, avaliação e arquivamento do documento em fase corrente e intermediária, visando a sua eliminação ou recolhimento para guarda permanente".

13 "Da criação, recepção, manutenção, uso e destinação de documentos, incluindo processos para capturar e preservar evidência de informação sobre atividades e transações registradas."

14 "[...] o processo sistemático de identificação[registro], criação, renovação e aplicação dos conhecimentos que são estratégicos na vida de uma organização".
} 
The systemic praxis of information flow makes it possible for organizational leadership to minimize its communication barriers, which brings data and information to the diverse individuals within intra and inter-organizational networks (Cunha, 2012). Such praxis, which is associated with Information and Communications Technologies and procedures for representing knowledge, constitutes advanced management techniques.

It has been highlighted that Information and Communication Technologies is a strong ally in constructing a learning organization, as long as these technologies are linked to the processes for representing knowledge. In turn, these processes are focused toward the "Notational or conceptual symbolization of human knowledge"15 and bring together techniques of classification, indexing, and the set of "Informational and linguistic"16 artifacts (Cunha; Cavalcanti, 2008, p.322, our translation).

According to Vasconcelos and Mascarenhas (2007), the structuring of information flow by means of Information and Communication Technologies makes it possible to "horizontalize" the organization, thereby diminishing or eliminating intermediate levels that would have previously made the flow of organizational knowledge rigid. Such technologies make it possible to create an organizational memory that has the ability to capture, store, and recover general and specific knowledge about organizational actions and consequently favors Organizational Learning and innovation.

Information and Communications Technologies are recognized as fundamental computational supports for the management system that includes Records Management, Information Management, and builds Knowledge Management. Therefore, irrespective of computational support, the competitiveness of an organization depends on organizational sharing and memory, which is verticalized by the processes that range from Records Management to Knowledge Management.

\section{Conclusion}

The main source of productivity in the twenty-first century is the capacity of organizations to (trans)form knowledge into socioeconomic assets, thereby paving the way for competitive advantages. Organizations are not isolated systems but, instead, they are components of numerous and varied systems that are integrated and dependent upon their composite parts: the individuals. Considering that knowledge is intrinsic to individuals, with the goal of making Organizational Learning feasible, this knowledge must be represented, made clear, and shared; this notion highlights the link between Records Management and Organizational Learning and consequently promotes innovation. Furthermore, Records Management supports organizational memory, which, in turn, is one of the foundational elements of Knowledge Management.

As discussed above, Knowledge Management consists of a set of guidelines, policies, strategies, practices, and tools to promote the generation, processing, and transformation of information into knowledge. This set requires skills that promote Organizational Learning and the recording of knowledge, which are linked to effective Records Management. The organization demonstrates its collective competence and intelligence to respond to its internal and external environment through Organizational Learning. Thus, the challenge for organizations is to identify and apply management models, with the goal of promoting conditions for the creation and use of knowledge and transforming these into innovations (e.g., products, services, management, and business). Current management models presuppose systems that will assure organizational competitiveness and efficiency. Moreover, these systems frequently include the representation of individuals' tacit knowledge and the socialization of such knowledge with the goal of creating the groundwork for a critical assessment of failures and errors.

Wherever Archival Science Records Management exists, individuals find resources to correct errors and also reflect on their underlying values, principles, and guidelines. This situation establishes double-loop learning, which requires the ability to understand the organization systemically and within the socioeconomic context. This process is facilitated when data and information are organized and preserved within the scope of current archival science. Thus, it is inferred that there is a close correlation between the conduct of the archivist and the

\footnotetext{
15 "Simbolização notacional ou conceitual do saber humano".

16 "Informáticos elinguisticos".
} 
processes of Knowledge Management and Organizational Learning for creating the groundwork for innovation.

When archivists know that their work contributes directly to Knowledge Management and Organizational Learning, these individuals become a key professional in the innovation processes. With its roots in the process of knowledge representation, archival Records Management becomes an advanced management technique that contributes directly to Organizational Learning and to the ability to innovate as an organization.

\section{References}

ARANTES, N. Sistemas de gestão empresarial: conceitos permanentes na administração de empresas válidas. 2.ed. São Paulo: Atlas, 1998.

ARGYRIS, C. On organizational learning. 13.ed. Malden: Blackwell, 2010.

BOURDIEU, P. A economia das trocas simbólicas. São Paulo: Perspectiva, 2009.

CHOO, C.W. A organização do conhecimento: como as organizações usam a informação para criar significado, construir conhecimento e tomar decisões. São Paulo: Senac, 2003.

CUNHA, F.J.A.P. Da adesão à participação em uma rede de hospitais como promoção da aprendizagem organizacionale da inovação gerencial: um olhar sobre a Rede InovarH-BA. 2012. Tese (Doutorado Multinstitucional e Multidisciplinar em Difusão do Conhecimento) - Faculdade de Educação, Universidade Federal da Bahia, Salvador, 2012.

CUNHA, M.B.; CAVALCANTI, R.O. Dicionário de biblioteconomia e arquivologia. Brasília: Briquet de Lemos, 2008.

FINANCIADORA DE ESTUDOS E PROJETOS. Organização para a cooperação e desenvolvimento econômico. Manual de Oslo: diretrizes para a coleta e interpretação de dados sobre inovação. 3.ed. Brasília: FINEP, 2005.

FRÓES BURNHAM, T. Complexidade, multirreferencialidade, subjetividade: três referências polêmicas para a compreensão do currículo escolar. In: BARBOSA, J. (Ed.). Reflexões em torno da abordagem multireferencial. São Carlos: EdUFSCar, 1998. p.35-56.

GIL, A.C. Métodos etécnicas de pesquisa social. São Paulo: Atlas, 1994.
GUINCHAT, C.: MENOU, M. Introdução geralàs ciências etécnicas da informação e documentação. Brasília: IBICT, 1994.

LOERMANS, J. Synergizing the learning organization and knowledge management. Journal of Knowledge Management, v.6, n.3, p.285-294, 2002.

MORIN, E. O método 1: a natureza da natureza. Porto Alegre: Sulina, 2005a.

MORIN, E. O método 3: conhecimento do conhecimento. Porto Alegre: Sulina, 2005b.

POLANYI, M. Personal knowledge: towards a post-critical philosophy. Chicago: University of Chicago, 1958.

ROUSSEAU, J.Y.; COUTURE, C. Os fundamentos da disciplina arquivística. Lisboa: Dom Quixote, 1998.

SANTOS, V.B. A prática arquivística em tempos de gestão do conhecimento. In: SANTOS, V.B.; INNARELLI, H.C.; SOUSA R.T.B. (Ed.). Arquivística:temas contemporâneos - classificação, preservação digital, gestão do conhecimento. Brasília: Senac, 2007.

SENGE, P. A quinta disciplina: arte e prática da organização que aprende. São Paulo: Best Seller, 2010.

TAKEUCHI, H.; NONAKA, I. Gestão do conhecimento. Porto Alegre: Bookman, 2008.

TERRA, J.C.C. Gestão do conhecimento: aspectos conceituais e estudos exploratórios sobre as práticas de empresas brasileiras. In: FLEURY, M.T.L.; OLIVEIRA JR., M.M. (Ed.). Gestão estratégica do conhecimento: integrando aprendizagem, conhecimento e competências. São Paulo: Atlas, 2001.

VASCONCELOS, I.F.G.; MASCARENHAS, A.O. Organizações em aprendizagem. São Paulo: Thomson Learning, 2007. 